\title{
DEK/NUP214 Fusion Protein
}

National Cancer Institute

\section{Source}

National Cancer Institute. DEK/NUP214 Fusion Protein. NCI Thesaurus. Code C99199.

A fusion protein encoded by the DEK/NUP214 fusion gene. This protein is comprised of the majority of protein DEK followed by $2 / 3$ of the C-terminal part of the nuclear pore complex protein Nup214. 